Chirurgia (2017) 112: 586-594

No. 5, September - October

Copyright@ Celsius

http://dx.doi.org/10.21614/chirurgia.112.5.586

\title{
Injuries of the Medial Clavicle: A Cohort Analysis in a Level-I-Trauma-Center. Concomitant Injuries. Management. Classification
}

\author{
Mustafa Sinan Bakir', David Merschin', Jan Unterkofler', Denis Guembel ${ }^{1,2}$, Andreas Langenbach ${ }^{3}$, \\ Axel Ekkernkamp ${ }^{1,2}$, Stefan Schulz-Drost ${ }^{1,3}$ \\ 'BG Hospital Unfallkrankenhaus Berlin gGmbH, Department of Trauma and Orthopedic Surgery, Berlin, Germany \\ ${ }^{2}$ Department of Trauma and Reconstructive Surgery and Rehabilitative Medicine, Universitätsmedizin Greifswald, Greifswald, Germany \\ ${ }^{3}$ University Hospital Erlangen, Department of Trauma and Orthopedic Surgery, Erlangen, Germany
}

\section{Corresponding author:}

Stefan Schulz-Drost, MD, PhD, FEBS

EmSurg.

BG Hospital Unfallkrankenhaus Berlin gGmbH, Warener Straße 7, 12683

Berlin, Germany

E-mail: stefan.schulz-drost@gmx.de
Received: 06.09.2017 Accepted: 20.09.2017

\section{Rezumat \\ Accidente ale claviculei mediane: o analiză de cohortă într-un centru de traumatologie de nivel 1. Leziuni concomitente. Management. Clasificare}

Introducere: Deşi leziunile la nivelul umărului sunt frecvente, cele ale claviculei mediane sunt prea puțin explorate. O clasificare aplicată este mai puțin utilizată ca management standard.

Metode: O analiză retrospectivă a leziunilor claviculare medii (MCI) pe parcursul unui stagiu de tratament de 5 ani într-un Centru de Traumatologie de nivel 1. Am analizat, printre altele, leziunile concomitente, strategiile de terapie şi clasificarea conform standardelor AO.

Rezultate: 19 (2,5\%) din 759 de leziuni claviculare au fost mediale (11 fracturi de tip A, 6 B şi 2 C), dintre care $27,8 \%$ au fost deplasate şi drept urmare tratate chirurgical. Osteosinteza cu placă fixă a fost utilizată în fracturi instabile şi reconstrucția ligamentelor în articulația sternoclaviculară (SCJ) în cazul întreruperii acestora. $84,2 \%$ dintre pacienți au prezentat leziuni concomitente relevante. Numeroase fracturi de mediane au fost codificate greşit ca fracturi mediale, ceea ce a limitat populatia de studiu

Concluzii: MCI a rezultat din mecanisme de vătămare cu impact puternic, adesea cu dislocare semnificativă şi leziuni concomitente. In ceea ce priveşte complexitatea leziunilor mediale, tratamentul ar trebui efectuat în spitale specializate. Fracturile instabile şi leziunile ligamentelor SCJ trebuie luate în considerare pentru tratamentul chirurgical. Fracturile mediane ar trebui să se 
distingă clar de cele mediale prin codificarea ICD-10. Sunt necesare studii suplimentare privind subtiparea clasificării AO pentru fracturile mediane de claviculă, inclusiv leziunile ligamentale.

Cuvinte cheie: centura scapulară, claviculă mediană, articulația sternoclaviculară, ligamentul sternoclavicular, ligamentul costoclavicular, ICD-10

\begin{abstract}
Introduction: Although shoulder girdle injuries are frequent, those of the medial clavicle are widely unexplored. An applied classification is less used just as a standard management.

Methods: A retrospective analysis of medial clavicle injuries (MCI) during a 5-year-term in a Level-1-Trauma-Center. We analyzed amongst others concomitant injuries, therapy strategies and the classification following the AO standards.

Results: 19 (2.5\%) out of 759 clavicula injuries were medial ones (11 A, 6 B and 2 C-Type fractures) thereunder 27,8\% were displaced and thus operatively treated Locked plate osteosynthesis was employed in unstable fractures and a reconstruction of the ligaments at the sternoclavicular joint (SCJ) in case of their disruption. $84,2 \%$ of the patients sustained relevant concomitant injuries. Numerous midshaft fractures were miscoded as medial fracture, which limited the study population. Conclusions: MCI resulted from high impact mechanisms of injury, often with relevant dislocation and concomitant injuries. Concerning medial injury's complexity, treatment should occur in specialized hospitals. Unstable fractures and injuries of the SCJ ligaments should be considered for operative treatment. Midshaft fractures should be clearly distinguished from the medial ones in ICD-10-coding. Further studies are required also regarding a subtyping of the AO classification for medial clavicle fractures including ligamental injuries.
\end{abstract}

Key words: shoulder girdle, medial clavicle, sternoclavicular joint, sternoclavicular ligament, costoclavicular ligament, ICD-10

\section{Introduction}

The clavicle plays a major role for the biomechanics of stability and range of motion in upper limbs (1). Injuries of the shoulder girdle are altogether a rather frequent type of injury concerning the upper extremities (2). The clavicle fractures solitarily represent depending on author - about $2.5-10.0 \%$ of all fractures $(3,4)$. Despite this fact the medial injuries are widely unexplored but essential for the functionality of the arm since the medial clavicle represents the only articular conjuction of the arm to the trunk. While the majority of clavicle fractures occur in the middle third, the medial ones are a rare speciality $(2,5)$. The majority with about $80 \%$ is located in the middle part; only $5 \%$ are situated at the medial end (3).
A lot of studies concerning the treatment of clavicle injuries have been published over the years. Nonetheless the discussion of conservative vs. operative treatment of clavicle associated injuries is an enduring issue, also based of an improvement in operation techniques and changed methods $(5,6)$.

A survey in trauma departments in Germany showed that more than $80 \%$ of the hospitals are not using any classification of clavicular injuries (7). Although there are common classification systems $(8,9)$, the majority has no strategic algorithm of treatment which seems to be caused by a lack of a practical classification system (7).

Regarding especially the injuries of the sternal end of the clavicle, a compulsive standard management is not evaluated so far (10). Different operative options are described (11-15). 
That is why our study presents a case series of medial clavicular injuries (MCI) including etiology, patterns of injuries, concomitant injuries and our therapy strategies. Due to the lack of preliminary work, we demonstrate complemental an approach to a classification of medial clavicle fractures.

\section{Methods}

The study is based on a retrospective analysis of data from a Level-1-Trauma-Center. We analyzed inpatients who have been treated in our department including the years 2012 to 2016.

Therefore we used our data base and searched for the corresponding ICD-10 codes (16) of injuries of the shoulder girdle. According to the $10^{\text {th }}$ revision of the International Statistical Classification of Diseases and Related Health Problems (ICD), we looked for the codes S42.01 (fracture of sternal end of clavicle), S42.02 (mid shaft clavicle fracture), S42.03 (fracture of lateral end of clavicle) as well as S43.1 (subluxation and dislocation of acromioclavicular joint) and S43.2 (subluxation and dislocation of sternoclavicular joint).

Extracting the medial injuries of the shoulder girdle, we looked for the codes S42.01 and S43.2. We picked these both as single and as combined injuries. We reselected them with regard to the exact location of the injury referring to radiologic investigations, to double check the correct coding. All cases were also scanned for circumstances of the accident, potential concomitant injuries, therapy strategies, days to a potential operation and duration of stay at intensive care unit (ICU).

The injuries of the medial clavicle were then categorized based on the classification by the AO Foundation (9). Finally the main classification groups were checked for possible subtypes of the included injuries.

\section{Results}

We analyzed a total number of 759 patients who showed at least one out of the five clavicle injuries (Fig. 1). Altogether, the data of 67

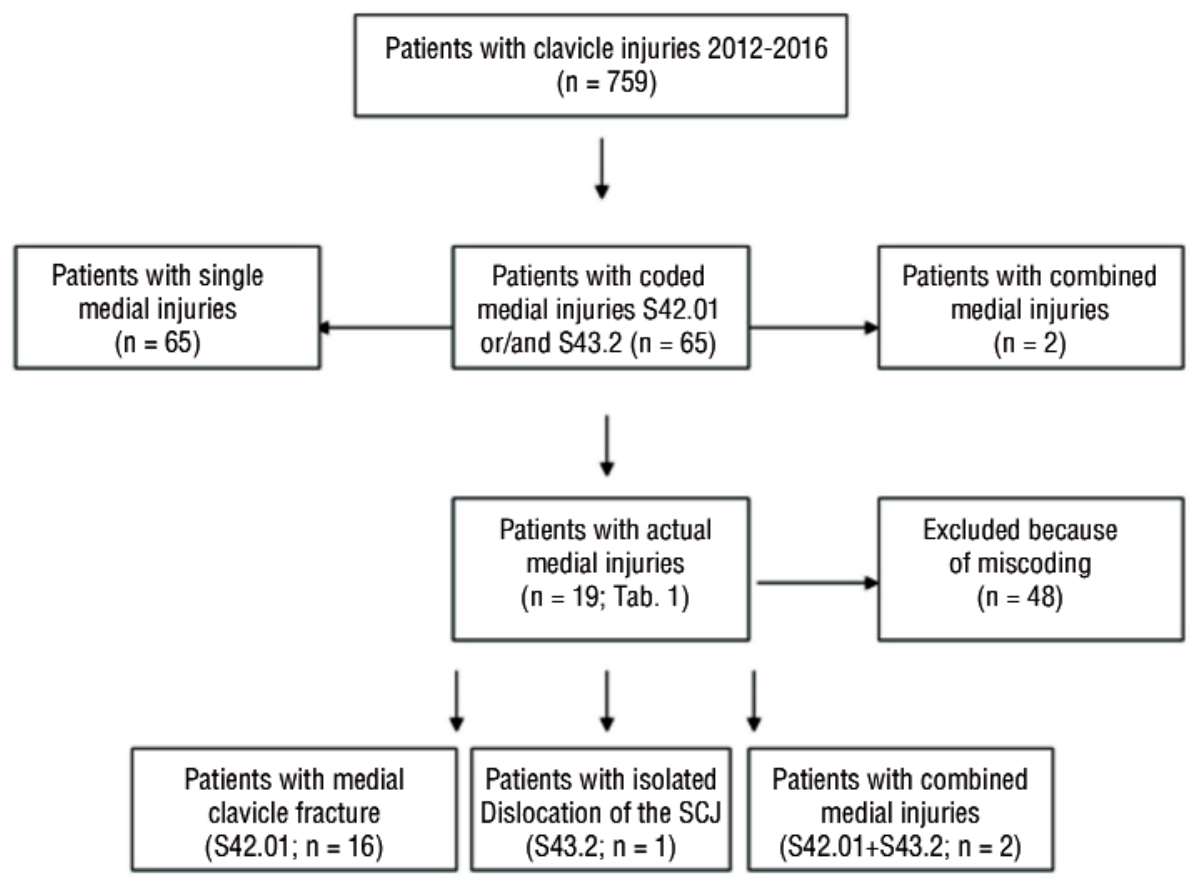

Figure 1. The collective. Injuries of the medial clavicle are rare. Only $8,8 \%$ out of all patients who suffered from a clavicle-related injury were coded as $\mathrm{MCl}$. Moreover 48 of them were apparently miscoded since they showed a midshaft fracture. This results in 2,5\% MCI out of all injuries with involvement of the clavicle. Thus $\mathrm{MCl}$ are rare types of injuries. 
patients with coded medial injuries were used for further investigation.

That means $8.8 \%$ of all clavicle injuries were coded as medial injuries. In fact the percentage of medial injuries was only $2.5 \%$ $(n=19)$. This implies that $71,6 \%$ of all coded medial injuries were miscoded mostly due to a false inclusion of midshaft fractures (Fig. 1).

The collective consists of one adolescent, thirteen men and five women (Table 1). The average age was 54,9 years ( $\min 13, \max 93$, SD 23,9). Two patients showed a combined MCI including dislocation of sternoclavicular joint (SCJ) (Fig. $3 A, B$ ) and a medial clavicle fracture $(\mathrm{MCF})$.
$68,4 \%$ of the medial injuries were treated conservatively, whereas the rest $(n=6)$ underwent an operation. In the latter case this was performed about seventeen days after the day of accident. But there was a large difference relating to the date of operation between the medial clavicular fractures with 6.7 days after accident in contrast to 33.5 days in case of sternoclavicular joint dislocation.

Different operative procedures were applied: Isolated MCF were treated by osteosythesis with a plate, once with a reconstruction plate, twice with a locking plate (Fig. 3). In case of a dislocation of the SCJ with rupture of the costoclavicular ligament (CCL), an open reduction

Table 1. The collective of medial clavicle injuries.

\begin{tabular}{|c|c|c|c|c|c|c|c|c|c|c|c|c|c|c|}
\hline $\begin{array}{l}\text { Case } \\
\text { nr. }\end{array}$ & $\begin{array}{l}\text { ICD-10 } \\
\text {-code }\end{array}$ & $\begin{array}{c}\text { AO } \\
\text { Class }\end{array}$ & $\begin{array}{l}\text { Alternative } \\
\text { Subtype }\end{array}$ & Gender & Age & $\begin{array}{l}\text { Mechanism } \\
\text { of injury }\end{array}$ & Treatment & Head & Thorax & $\begin{array}{l}\text { Shoulder } \\
\text { girdle }\end{array}$ & Limb & Trunk & Abdomen & $\begin{array}{l}\text { days } \\
\text { ICU }\end{array}$ \\
\hline 1 & S42.01 & $15.1 \mathrm{~A}$ & A1 & $\mathrm{m}$ & 52 & motorcycle & kons & +++ & +++ & & & +++ & & 20 \\
\hline 2 & S42.01 & $15.1 \mathrm{~A}$ & A1 & $f$ & 82 & Car occupant & kons & +++ & +++ & & & ++ & & 8 \\
\hline 3 & S42.01 & $15.1 \mathrm{~A}$ & $\mathrm{~A} 2$ & $\mathrm{~m}$ & 53 & High fall & kons & + & & & + & + & & 11 \\
\hline 4 & S42.01 & $15.1 \mathrm{~A}$ & $\mathrm{~A} 2$ & $\mathrm{~m}$ & 33 & Bicycle & $\begin{array}{l}\text { OP } \\
\text { (locked plate) }\end{array}$ & & & & & & & 0 \\
\hline 5 & S42.01 & $15.1 \mathrm{~A}$ & A3 & $\mathrm{m}$ & 67 & motorcycle & kons & & ++ & & + & & & 0 \\
\hline 6 & S42.01 & $15.1 \mathrm{~A}$ & A3 & $\mathrm{m}$ & 45 & bicycle & $\begin{array}{l}\text { OP } \\
\text { (locked plate, } \\
\text { ACG TightRope }{ }^{\circledR} \text { ) }\end{array}$ & & ++ & S43.1 & & & & 2 \\
\hline 7 & S42.01 & $15.1 \mathrm{~A}$ & B1 & $\mathrm{m}$ & 23 & Direct collision & kons & & & & ++ & & & 0 \\
\hline 8 & S42.01 & $15.1 \mathrm{~A}$ & B1 & $f$ & 88 & Low fall & kons & $(+)$ & & & & & & 7 \\
\hline 9 & S42.01 & $15.1 \mathrm{~A}$ & $\mathrm{~B} 1$ & $\mathrm{~m}$ & 81 & high fall & kons & +++ & +++ & & ++ & & & 12 \\
\hline 10 & S42.01 & $15.1 \mathrm{~A}$ & B1 & $\mathrm{m}$ & 28 & motorcycle & kons & & & & +++ & + & & 0 \\
\hline 11 & S42.01 & $15.1 \mathrm{~A}$ & B2 & $\mathrm{m}$ & 30 & high fall & kons & + & + & & & + & & 1 \\
\hline 12 & S42.01 & $15.1 \mathrm{~B}$ & B2 & $\mathrm{m}$ & 58 & Car occupant & kons & & ++ & & +++ & + & + & 3 \\
\hline 13 & S42.01 & $15.1 \mathrm{~B}$ & B2 & $f$ & 93 & Low fall & kons & & & & + & & & 0 \\
\hline 14 & S42.01 & $15.1 \mathrm{~B}$ & B2 & $\mathrm{m}$ & 13 & high fall & OP (suture) & & & & & & & 0 \\
\hline 15 & S42.01 & $15.1 \mathrm{~B}$ & B3 & $f$ & 84 & bicycle & kons & & & & & + & & 6 \\
\hline 16 & S42.01 & $15.1 \mathrm{~B}$ & $\mathrm{C} 2$ & $\mathrm{~m}$ & 50 & $\begin{array}{l}\text { Direct } \\
\text { collision }\end{array}$ & $\begin{array}{l}\text { OP } \\
\text { (SCL Suture, } \\
\left.\text { CCLTightRope }{ }^{\circledR}\right)\end{array}$ & & ++ & S43.2 & & & & 0 \\
\hline 17 & S42.01 & $15.1 \mathrm{~B}$ & $\mathrm{C} 2$ & $f$ & 65 & Low fall & $\begin{array}{l}\text { OP } \\
\text { (locked plate, } \\
\text { lag screw) }\end{array}$ & & & & & & & 0 \\
\hline 18 & S43.2 & $15.1 \mathrm{C}$ & $\mathrm{C} 2$ & $\mathrm{~m}$ & 42 & motorcycle & kons & + & ++ & $\begin{array}{l}\text { S43.1, } \\
\text { S42.01 }\end{array}$ & + & & & 27 \\
\hline 19 & S43.2 & Allmann III* & C1 & $\mathrm{m}$ & 57 & high fall & $\begin{array}{l}\text { OP (SCL Suture, } \\
\left.\text { CCLTightRope }{ }^{\circledR}\right)\end{array}$ & & ++ & S43.1 & & & & 0 \\
\hline
\end{tabular}

18 cases could be classified following the AO standards of the subsegment (1) of the clavicle (15).

15.1A: outside the SCJ (extra articular)

15.1B: with involvement of the SCJ (intra articular)

15.1C: comminuted (multifragmentary)

${ }^{*}$ Case-nr. 19 showed anterior SCJ luxation without any fracture which is known as type Allmann III

Considering the concomitant injuries of the SCJ and its ligaments SCL and CCL in fractures of the medial clavicle one alternative classification showed a different distribution of the severity of the cases $(6 \mathrm{~A}, 9 \mathrm{~B}, 4 \mathrm{C})$. The different subtypes of $\mathrm{MCl}$ are described in fig. 4.

degree of injury: + mild, ++ relevant, +++ severe 


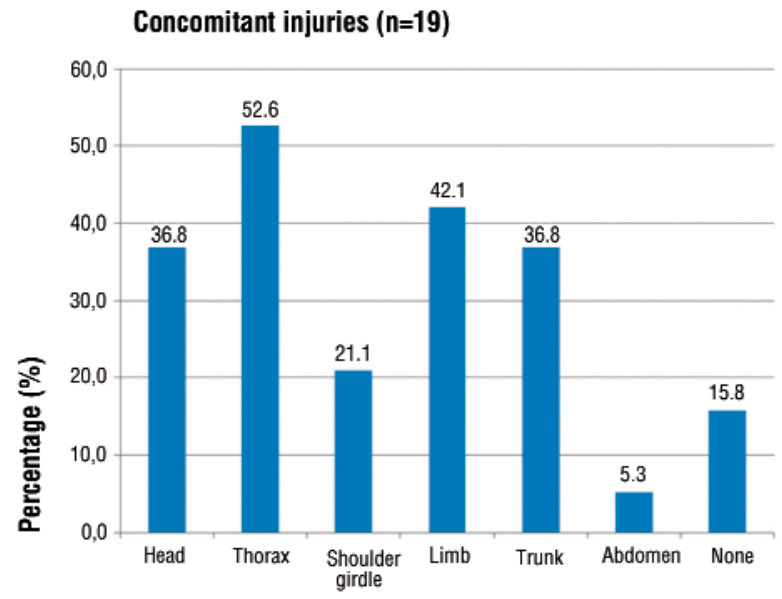

Figure 2. Concomitant injuries. Only $15,8 \%$ out of the collective showed an isolated $\mathrm{MCl}$ whereas every fifth patient had another injury involving the shoulder girdle. More than every second patient showed additional injuries at the thorax, especially at the chest wall with concomitant rib fractures.

and internal fixation of the CCL with two TightRopes ${ }^{\circledR}$ in between the clavicle and the first rib was performed $(n=2)$. Any rupture of the sternoclavicular ligaments (SCL) was addressed by additional sutures and sternoclavicular FiberWire ${ }^{\circledR}$ cerclage (Fig. 2c) (17). In one case a capsular duplication was added to maximize the stabilization.

Referring to the classification by $\mathrm{AO}$ Foundation, we categorized the MCF in three types: 15.1 A (extra articular), $15.1 \mathrm{~B}$ (intra articular) and 15.1 C (multifragmentary). More than half of them belonged to the extra articular category $(n=11)$, while $31,6 \%$ were part of group $15.1 \mathrm{~B}$ and $10,5 \%$ were multifragmentary fractures. Obviously a correlation existed between the complexity of the fracture and the proportion of operative treatment in these categories: the more complex the fracture, the more the decision for operation was made (15.1 A: 18,2\%; 15.1 B: $50 \% ; 15.1$ C: 50.0\%). (Table 1)

$84,2 \%$ of the patients were adversely affected by concomitant injuries (Fig. 4). SCJ dislocations were always accompanied to severe thoracic traumata which are the most prevalent concomitant injury in medial shoulder girdle injuries appearing in more than half of the cases. They often went along with serial rib

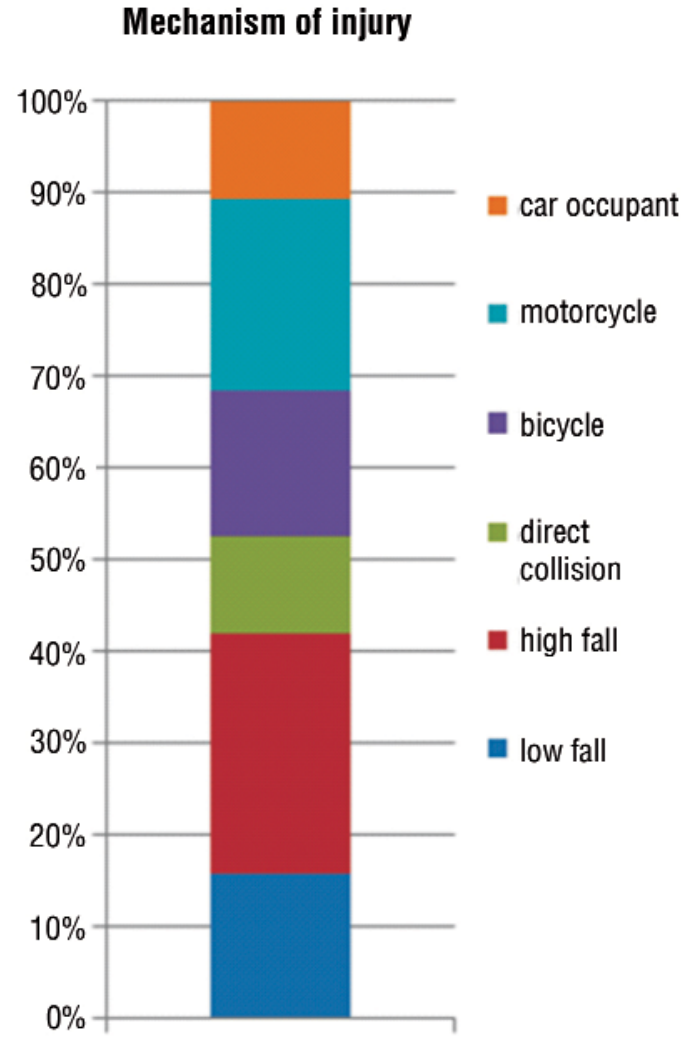

Figure 3. Mechanisms of injury. High impact mechanisms were predominantly the cause of medial clavicle injuries. Low fall injuries could cause $\mathrm{MCl}$ primarily in the elder patients (Table 1).

fractures as well as pneumothorax and hemothorax. Furthermore the following co-injuries arised frequently in descending occurence: trauma of the limbs, trunk and craniocerebral injuries. In $21.1 \%$ we found a combination of shoulder girdle injuries like an additional dislocation of the acromioclavicular joint, which was contemporaneously operated in one case (Table 1, Fig. 2).

Dislocation of the SCJ in particular as a rare injury was in every case associated with another injury of the shoulder girdle: once to a dislocation of the acromioclavicular joint, once to a fracture of the sternal end of clavicle and once to both of them. One patient, who was directly admitted to our department, suffered from a severe craniocerebral injury and his SCJ was treated conservatively. The other two patients were initially treated in other hospitals and 


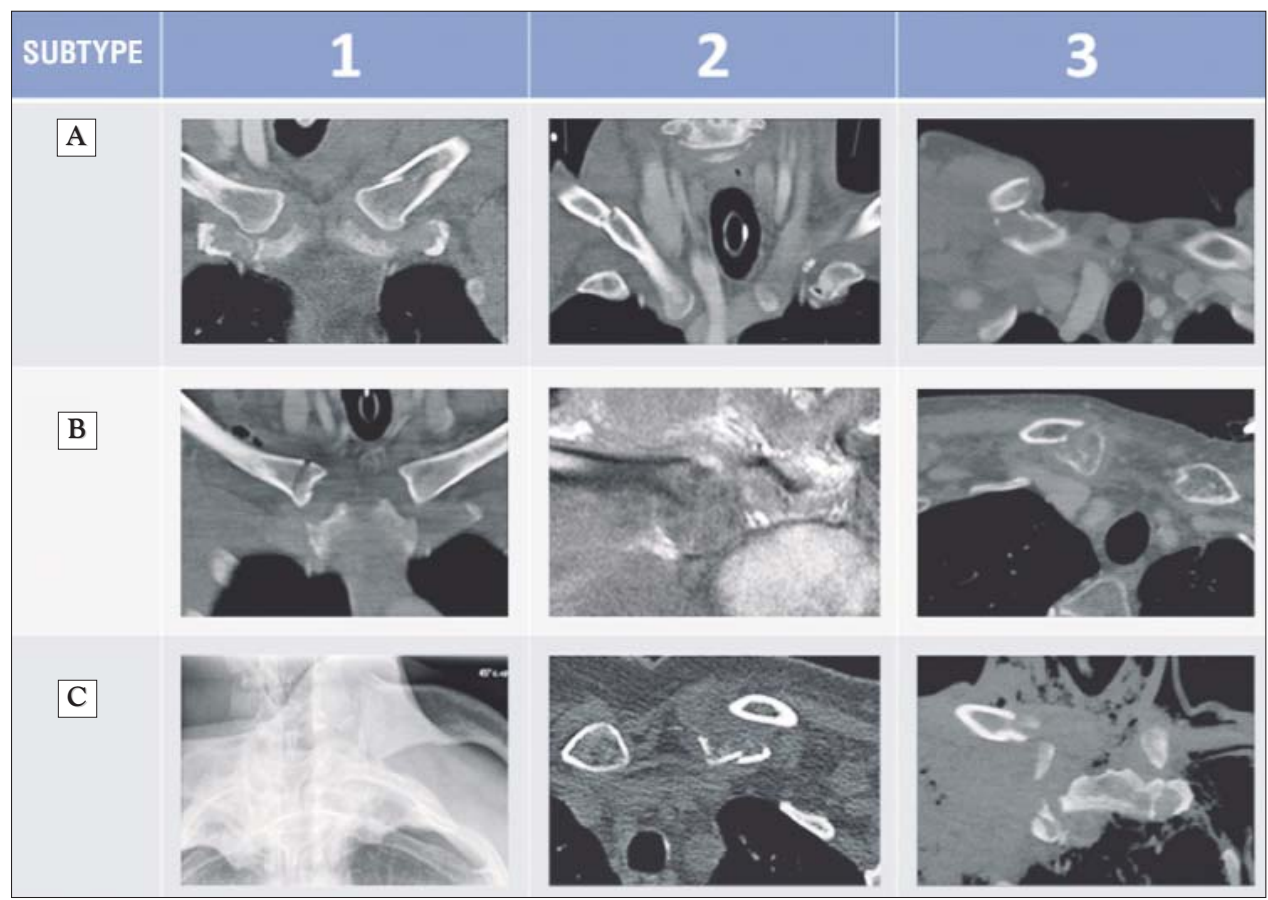

Figure 4. Possible subtypes of medial clavicle injuries. (A) without involvement of the SCJ (extraarticular); A1 spiral or oblique fracture; A2 transverse fracture; A3 comminuted fracture (multifragmentary). (B) partial involvement of the SCJ (partial joint fracture; at least one ligament stable); B1 "inner fracture" (in between the SCL and the CCL; both of the ligaments stable); B2 involvement of the medial main fragment and the SCL, stable CCL and lateral fragment; B3 involvement of the lateral main fragment and the CCL, stable SCL and medial fragment. (C) unstable SCJ with rupture of the CCL; C1 SCJ dislocation with rupture of SCL and CCL without a fracture (=Allmann III anterior and posterior); $\mathrm{C} 2$ partial SCJ fracture with remaining fragment with attachment to the CCL and the SCL; C3 disruption of SCL and CCL with additional fracture in between the ligaments of the SCJ

then transferred to our department due to the complexity of their injuries for definitive treatment. This caused a time delay and therefore the stabilization of the SCJ dislocation was performed 13 days and 54 days after accident. In the latter case the severity of the MCI was initially underestimated, wherefore conservative treatment failed.

$10(52.6 \%)$ of the patients initially needed to be treated at the intensive care unit (ICU). The average duration of stay at ICU was 5.1 days (min: 0, max: 27, SD: 7,7). This high amount of ICU patients is attributed to the described common concomitant injuries as well as the usual severe trauma mechanism which determines each other. The injuries prevalently resulted from high-impact traumata: 47,4\% were involved in road traffic accidents (RTA) by car, motorbike or bicycle and $36,1 \%$ were caused by high falls or severe direct collision $(n=2)$, thereunder a heavy falling balk and a collision of a swimmer in between a ship and a wall of the harbour (Fig. 3).

\section{Discussion}

The clavicle is considered to be the gatekeeper of the thorax. In polytrauma patients, a clavicle fracture is easily diagnosed during primary survey and may indicate underlying thoracic injury, as the rate and extent of concomitant thoracic injury are high (18). Although there is no difference in the distribution of medial clavicle fractures between monotrauma and polytrauma patients (19), the dislocation of sternoclavicular joint is often associated of a high force by trauma mechanism (20). There is also a higher rate of severe co-injuries in our patients with medial clavicular injuries in comparison to patients with any shoulder 


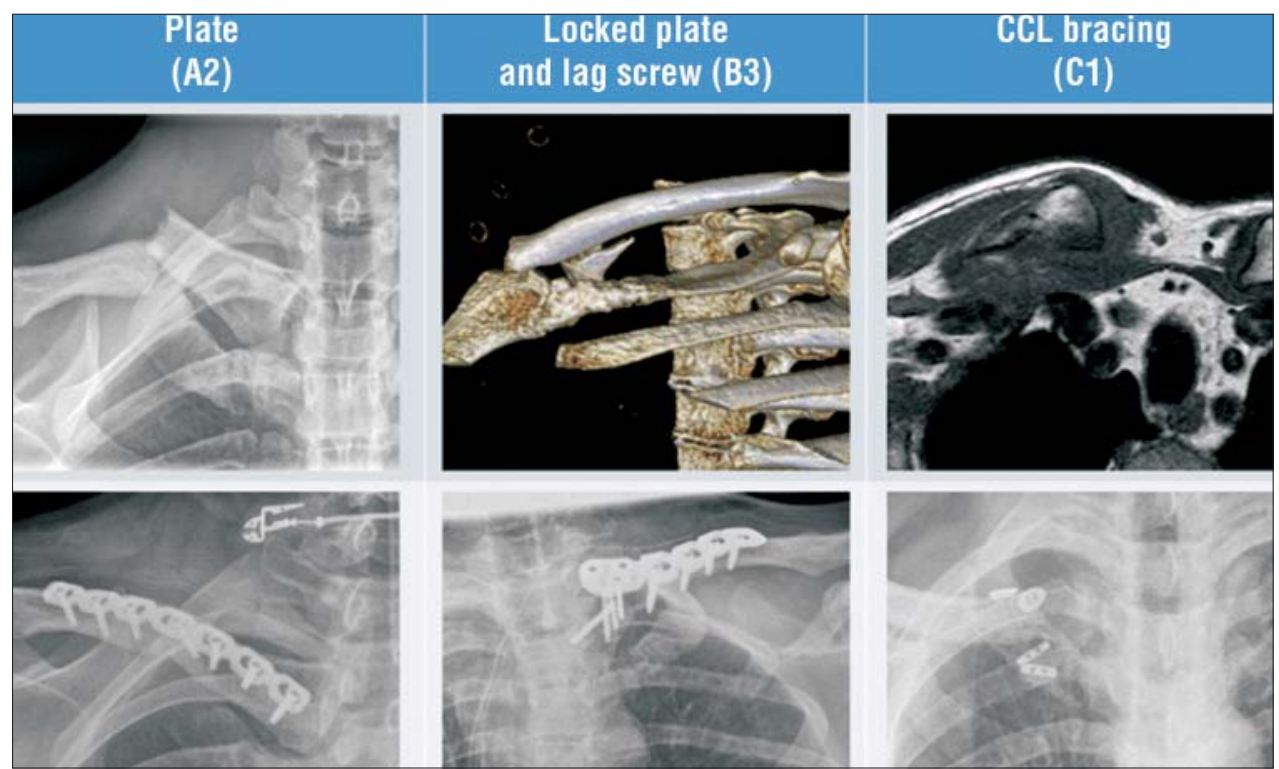

Figure 5. Examples for operative treatment of medial clavicle injuries. A-Type fractures do not involve the SCJ and can be fixed with plate and screws or a locked plate. Oblique fractures (A1) could benefit from an additional lag screw as well as those with partial avulsion of the SCJ with a remaining fragment which shows intact ligaments such as SCL and CLL (B3). Once the CCL shows disruption the medial clavicle may show severe displacement. CCL could be reconstructed with employment of a bracing technique, eg. with TightRope®-Sutures. In case of additional fractures (C-Type) of the medial clavicle those sutures could be induced through an additional plate for example.

girdle injury in general (20) regarding the head (medial $36,8 \%$ vs. overall $31.5 \%$ ) and thoracic injury (medial 52.6\% vs. overall 36.8\%) (Fig. 2). This underlines the high impact which usually causes MCI and the severe resulting trauma.

In contrast to the acromioclavicular joint dislocation which is usually easy to detect by clinical examination, the dislocation of sternoclavicular joint is sufficiently known as a rare injury $(21,22)$. It is often initially missed or underestimated so that cross-sectional imaging is required to discover $(14,23,24)$. In terms of an adequate trauma mechanism, a special attention should be paid to this entity. Especially in case of coexistant injuries as described in this work, this should be focused because of the high correlation.

Although not every dislocation of the sternoclavicular joint needs a surgical intervention, the treatment should occur in a level one trauma center because of the potential lifethreatening effects and co-injuries and the fact that there is a kind of reluctance for orthopaedic surgeons to operate in this usually unfamiliar area (24). Therefore, the register for very severe injury procedures of the statutory accident insurance in Germany contains the injuries of the medial clavicle which entails a treatment by specially qualified traumatologists within certified trauma centres (25).

Unless a fracture of the clavicle was a domain of conservative treatment in the past, a tendency to increasing operative procedures is noticeable (26). A survey in German trauma departments confirms our approach of operative treatment as proceeded: $81 \%$ would also do operative procedures in case of ipsilateral concomitant injuries of the shoulder girdle (7). The high amount of concomitant injuries in MCI and the intense forces which appear at this joint, favours an operative treatment in case of unstable fractures and dislocations of the SCJ with rupture of the CCL. This is according to more recent studies which show a tendency towards operative treatment of SCJ dislocations and MCF in contrast to the 
prevailing opinion so far $(15,27)$.

All patients showed sufficient postoperative results which seem even to be superior to those which had been recently described in an analysis of operatively treated SCJ dislocations. In these patients the SCL was reconstructed employing FiberWire ${ }^{\circledR}$ whereas the CLL was not adressed (15). Because of the fact that the longest follow-up interval after operative treatment is maximum 2.5 years, long-term analysis is needed. Relating to diverging evaluations between doctors and patients after clavicle injuries, our results could be assessed as satisfying (28).

As a side effect we developed a considerable amount of combined injuries of the shoulder girdle. The epidemiology of the combination between the single types of injuries should be another starting point to evaluate this so far only in case reports described entity (29-31).

As a limitation we could have shown that almost $3 / 4$ of all as medial coded fractures of the clavicle were miscoded in the ICD-10 system since a mix-up of the medial and the middle third of the clavicle is rather common nationwide (10). Therefore bidirectional bias could not be suspended. After adjusting our data set, the results are conform with the epidemiology as described in literature (4). This miscoding generally illustrates a problem in analyzing routine data with regard to ICD-10 codes. A more precisely analysis would be possible from data of large trauma registries with an individual review and the possibility of a radiological analysis of the morphology of the fractures.

Unfortunately, a more extensive conclusion is not possible because of the limited number of cases of the rare MCI in this cohort study. Therefore further studies in terms of controlled trials or retrospective multicenter analysis is required. Regarding to a larger cohort, an adaption and development of the $\mathrm{AO}$ classification for $\mathrm{MCF}$ is possible to close the gap of disregarding the ligamental structures. An add-on for subtypes following our proposal which is similar to the classification of lateral fractures of the clavicle is conceivable and desirable as the CCL is meant to be the most important stabilizer of the medial clavicle. Another approach to a comprehensive classification of sternal end injuries of the clavicle has not been published so far.

\section{Conclusions}

Further research is needed considering a subtyping classification of $\mathrm{MCF}$ with regard to the ligaments of the SCJ. There is an additional demand of studies including a larger patient population and long term follow up of the different treatment strategies.

\section{Acknowledgements}

Contents of this manuscript had been presented by S.S.D and D.M. during the $18^{\text {th }}$ European Congress of Trauma and Emergency Surgery, 7.-9. May 2017 in Bucharest, Romania.

We thank Mrs. Becht and Professor Mutze and the team from the institute of radiology for the friendly support in providing the X-Rays as well as the establishment of an in housestandard for the imaging in injuries of the medial clavicle.

\section{Conflicts of Interest}

The senior author has a consultant agreement with DePuySynthes and he is an advisory member of the AO TK Thoracic Surgery Expert Group (THEG). The other authors are not involved in any COI.

\section{Ethical Policies}

This is a retrospective study. No experiments on humans or animals had been done.

\section{Financial Support}

No funds had been received in connection to this study.

\section{References}

1. Moseley HF. The clavicle: its anatomy and function. Clin Orthop Relat Res. 1968;58:17-27.

2. Postacchini R, Gumina S, Farsetti P, Postacchini F. Longterm 
results of conservative management of midshaft clavicle fracture. Int Orthop. 2010;34(5):731-736. doi:10.1007/s00264-009-0850-x.

3. Klonz A, Hockertz T, Reilmann H. Clavicular fractures. Unfallchirurg. 2001;104(1):70-81; quiz 80. German

4. Postacchini F, Gumina S, De Santis P, Albo F. Epidemiology of clavicle fractures. J Shoulder Elbow Surg. 2002;11(5):452-456.

5. Robinson CM. Fractures of the clavicle in the adult. Epidemiology and classification. J Bone Joint Surg Br. 1998;80(3):476-484.

6. Canadian orthopaedic trauma society. Nonoperative treatment compared with plate fixation of displaced midshaft clavicular fractures. A multicenter, randomized clinical trial. J Bone Joint Surg Am. 2007:89(1):1-10.

7. Pieske 0, Dang M, Zaspel J, Beyer B, Löffler T, Piltz S. Midshaft clavicle fractures--classification and therapy. Results of a survey at German trauma departments. Unfallchirurg. 2008;111(6):387-94. doi: 10.1007/s00113-008-1430-z. German

8. Allman FL Jr. Fractures and ligamentous injuries of the clavicle and its articulation. J Bone Joint Surg Am. 1967;49(4):774-84.

9. A0 Foundation. Schatzker J, Andermahr J, McKee M, Nam D. AO Surgery Reference. Classification of clavicle injuries. URL:https:// www2.aofoundation.org/wps/portal/surgery?showPage=diagnosis \&bone=Clavicle\&segment=Nonsegmented, last appeal: 21/07/2017.

10. Unterkofler J, Schulz-Drost S, Ekkernkamp A. Epidemiologie der Verletzungen des sternoklavikularen Gelenks und der angrenzenden Klavikula in Deutschland. Presentation at German Congress of Orthopedic and Trauma Surgery 2016 (DKOU 2016). 2528/10/2016. Session WI31-1348: Wissenschaftliches Thema Frakturen des Schultergürtels.

11. Guan JJ, Wolf BR. Reconstruction for anterior sternoclavicular joint dislocation and instability. J Shoulder Elbow Surg. 2013;22(6):77581. doi: 10.1016/j.jse.2012.07.009. Epub 2012 Sep 13.

12. Aydın E, Dülgeroğlu TC, Ates A, Metineren H. Repair of Unstable Posterior Sternoclavicular Dislocation Using Nonabsorbable Tape Suture and Tension Band Technique: A Case Report with Good Results. Case Rep Orthop. 2015;2015:750898. doi: 10.1155/2015/ 750898. Epub 2015 Nov 3.

13. Hwang WJ, Lee Y, Yoon YS, Kim YJ, Ryu HY. Surgical treatment of sternoclavicular joint dislocation using a T-plate. Korean J Thorac Cardiovasc Surg. 2016;49(3):221-3. doi: 10.5090/kjtcs.2016.49. 3.221. Epub 2016 Jun 5.

14. Morell DJ, Thyagarajan DS. Sternoclavicular joint dislocation and its management: a review of the literature. World J Orthop. 2016; 7(4):244-50. doi: 10.5312/wjo.v7.i4.244. eCollection 2016 Apr 18.

15. Adamcik S, Ahler M, Gioutsos K, Schmid RA, Kocher GJ. Repair of sternoclavicular joint dislocations with FiberWire $\circledast$. Arch Orthop Trauma Surg. 2017;137(3):341-345. doi: 10.1007/s00402-0172632-z. Epub 2017 Jan 21.

16. World Health Organization. International Statistical Classification of Diseases and Related Health Problems, $10^{\text {th }}$ Revision. 2017.

17. Unterkofler J, Merschin D, Langenbach A, Ekkernkamp A, SchulzDrost S. Injuries of the sternoclavicular joint - an innovative approach in the management of a rare injury: tight rope fixation of the costo- clavicular ligament. Chirurgia (Bucur). 2017;112(5):In press.

18. van Laarhoven JJ, Hietbrink F, Ferree S, Gunning AC, Houwert RM, Verleisdonk EM, et al. Associated thoracic injury in patients with a clavicle fracture: a retrospective analysis of 1461 polytrauma patients. Eur J Trauma Emerg Surg. 2016 Apr 23. [Epub ahead of print]

19. Ferree S, van Laarhoven JJ, Houwert RM, Hietbrink F, Verleisdonk EJM, Leenen LP. Distribution and treatment of clavicular fractures in monotrauma and polytrauma patients. J Trauma Manag Outcomes. 2014;8:17. doi: 10.1186/1752-2897-8-17. eCollection 2014.

20. Gottschalk HP, Browne RH, Starr AJ. Shoulder girdle: patterns of trauma and associated injuries. J Orthop Trauma. 2011;25(5):26671. doi: 10.1097/BOT.0b013e3181e47975.

21. Kahle M, Filler RD, Forster L. Luxations in the sternoclavicular joint. Aktuelle Traumatol. 1990;20(2):83-6.

22. Sons HU, Danneberg A, Jerosch J. Diagnosis and therapy of sternoclavicular joint dislocation. Z Orthop Ihre Grenzgeb. 1992; 130(1):22-30.

23. Balcik BJ, Monseau AJ, Krantz W. Evaluation and treatment of sternoclavicular, clavicular, and acromioclavicular injuries. Prim Care. 2013;40(4):911-23, viii-ix. doi: 10.1016/j.pop.2013.08.008. Epub 2013 Sep 26.

24. Sewell MD, Al-Hadithy N, Le Leu A, Lambert SM. Instability of the sternoclavicular joint: current concepts in classification, treatment and outcomes. Bone Joint J. 2013;95-B(6):721-31. doi: 10.1302/ 0301-620X.95B6.31064.

25. DGUV, SVLFG. Verletzungsartenverzeichnis mit Erläuterungen unter Einschluss des Schwerstverletzungsartenverfahrens. 1. Juli 2014. http://www.dguv.de/medien/landesverbaende/de/med_reha/documents/verletz3.pdf.

26. Zlowodzki M, Zelle BA, Cole PA, Jeray K, McKee MD; EvidenceBased Orthopaedic Trauma Working Group. Treatment of acute midshaft clavicle fractures: systematic review of 2144 fractures: on behalf of the Evidence-Based Orthopaedic Trauma Working Group. J Orthop Trauma. 2005;19(7):504-7.

27. Sidhu VS, Hermans D, Duckworth DG. The operative outcomes of displaced medial-end clavicle fractures. J Shoulder Elbow Surg. 2015; 24(11):1728-34. doi: 10.1016/j.jse.2015.04.011. Epub 2015 Jul 2.

28. McKee MD, Pedersen EM, Jones C, Stephen DJ, Kreder HJ, Schemitsch EH, et al. Deficits following nonoperative treatment of displaced midshaft clavicular fractures. J Bone Joint Surg Am. 2006;88(1):35-40.

29. Marjoram TP, Chakrabarti A. Segmental clavicle fracture and acromioclavicular joint disruption: an unusual case report. Shoulder Elbow. 2015;7(3):187-9. doi: 10.1177/1758573214564496.

30. Mohammed KD, Stachiw D, Malone AA. Type IV acromioclavicular joint dislocation associated with a mid-shaft clavicle malunion. Int J Shoulder Surg. 2016;10(1):37-40. doi: 10.4103/0973-6042. 174518.

31. Sharma N, Mandloi A, Agrawal A, Singh S. Acromioclavicular joint dislocation with ipsilateral mid third clavicle, mid shaft humerus and coracoid process fracture - a case report. J Orthop Case Rep. 2016;6(2):24-27. 